American Journal of Environmental Sciences 6 (1): 95-102, 2010

ISSN 1553-345X

(C) 2010 Science Publications

\title{
Analyzing of Trade Barriers to Timber Trade Policy
}

\author{
Rabiul Islam, Shaharuddin Mohamad Ismail and Chamhuri Siwar \\ Institute for Environment and Development, (Lestari), University Kebangsaan Malaysia, \\ 43600 UKM Bangi, Selangor, Malaysia
}

\begin{abstract}
Problem statement: This study investigated the issues of trade barriers to timber trade in Malaysia. In recent years, there has been decreasing the trade barriers to timber trade in Malaysia. Approach: Trade barriers to timber trade are an important role in the forest economics sector and take a major player in Malaysia's economic growth. There is a growing concern that trade barriers to timber trade are creating both direct and indirect opportunities to environmental trade issues. Results: We analyzed the role of trade barriers to timber trade and the barriers of timber trade policy in Malaysia. Conclusion: We explained tariff removals of timber trade in Malaysia. The purpose of this study is to highlight and clarify the impacts on trade barriers to timber trade in Malaysia.
\end{abstract}

Key words: Trade barrier, timber trade, forest economics sector

\section{INTRODUCTION}

Definition of trade barriers: Trade barriers to timber trade are an important role in the forestry sector and take a major player in Malaysia's economic growth. Rytkonen (2003) stated that barriers to trade are policies or actions which interfere with free market buying and selling of goods and services internationally. Tariffs are widely used to protect domestic producers' incomes from foreign competition and non-tariffs are used to restrict imports. Zhu et al. (2001) analyses the effects of accelerated tariff liberalization on the forest products sector and tariff changes on forest product trade have been studied mostly with single-country partial equilibrium approach.

Trade in timber products has generally benefited from successive postwar GATT agreements. Trade in forest products has become increasingly global, with various forest products growing exporting and importing countries. In recent years, there has been decreasing the tariff barriers to timber products trade particularly in the post-Tokyo Round era (Barbier, 1995; 1999). Producer countries have introduced export bans, restrictions, quotas and taxes to increase rent capture from tropical forest resource and to create incentives for domestic further processing.

There are three categories of trade barriers: Tariffs, Non-Tariff Measures (NTMs) and trade impediments, which affect the forestry sector (Bourke and Leitch, 2000). The discussion on international trade regime in forest products tends to focus on tariff and non-tariff measures especially in relation to the WTO/GATT trade negotiations. Bourke (1995) states that many environmental actions can be considered to be trade barriers which go against internationally agreed trade rules, such as GATT/WTO seeking to liberalize world trade in forest products. All the various environmental impacts of trade policies on natural resources are difficult to assess, but evidence indicates the presence of both negative and positive impacts.

Tariff trade barriers: Tariffs are the most widely used and obvious means of providing protection. The most common form is an ad-valorem tariff where the duty is a fixed proportion of the value of the imported item. There is a tendency for tariff rates to be lowest on unprocessed products and to rise with increased processing. A number of measures affect trade in all sectors including the forest and forest products sector, such as tariff levels and tariff escalation. Average tariffs rates on timber products in the main importing countries are relatively low, generally less than $5 \%$. However, tariff escalation exists. In most developed country markets unprocessed wood products such as wood-based panels (particularly plywood), wood work items, some paper products and furniture often fall in the $10-15 \%$. It should be recalled that tropical timber products account for a large share of the exports of plywood and panels. Tariff is linked in certain cases to an arrangement such as the Generalized System of Preferences (GSP) or duty-free quota, which could be

Corresponding Author: Rabiul Islam, Institute for Environment and Development (Lestari),

University Kebangsaan Malaysia, 43600 UKM Bangi, Darul Ehsan, Selangor, Malaysia 
looked at as part and parcel of the tariff structure. Import tariff on imported tropical timber makes it less competitive. Many developing countries manage to avoid paying the full tariff rates as they are covered by various preference schemes, notably the UNCTAD Generalized System of Preferences (GSP) applied by developed countries. This tendency, known as tariff escalation, makes it more difficult for exporters to trade in more processed products. Tariff rates on timber products in developing countries tend to be much higher than those in developed countries. As a result of the Uruguay Round, these tariff levels will be reduced, but in general will remain significantly higher than those of developed countries (Bourke, 1988).

Non-tariff trade barriers: Non-tariff barriers include laws, regulations, policies and practices that either protect domestically produced goods from the full brunt of foreign competition, or artificially stimulate the exports of domestic products. The Fig. 1 gives some examples of non-tariff barriers affecting tropical timber products.

A variety of Non-Tariff Measures (NTMs) exist for timber products. Non-tariff measures used are wideranging. NTMs are harder to estimate their impact than tariff measures. They include direct quantitative restrictions such as import quotas, tariff quotas or voluntary export restraints, technical standards and plant health (phytosanitary) standards and sometimes cumbersome import licensing, customs procedures and domestic policies (Philippidis and Sanjuan, 2007). The use of import quotas for forest products is declining, but in some cases still causes difficulties. In contrast, the use of export restrictions, particularly on logs, has been increasing. Developing countries have employed the most export restrictions as revenue-generators, as means to encourage value-added processing of wood products and more recently to reduce harvesting levels. Certain domestic policies affect the competitiveness of foreign producers by reducing domestic producers' costs. Forest products are less affected by NTBs than most other products. Quantitative restrictions, price controls and other forms of NTBs are not widespread (Bourke, 1988).

Bourke and Leitch (1998) states that technical and phytosanitary standards are likely to continue to create difficulties for exporters for many years to come. Technical regulations and standards related to the protection of animal and plant life from pests and diseases; to human health and safety and to maintenance of air, water and land quality, result in considerable adjustment and readjustment in terms of trade. By changing relative costs and comparative advantages and consequently trade patterns, they create difficulties for trade.

The aim of this study is to obtain the reduced trade barriers to timber trade and the effect of non-tariff trade barriers to timber trade in Malaysia.

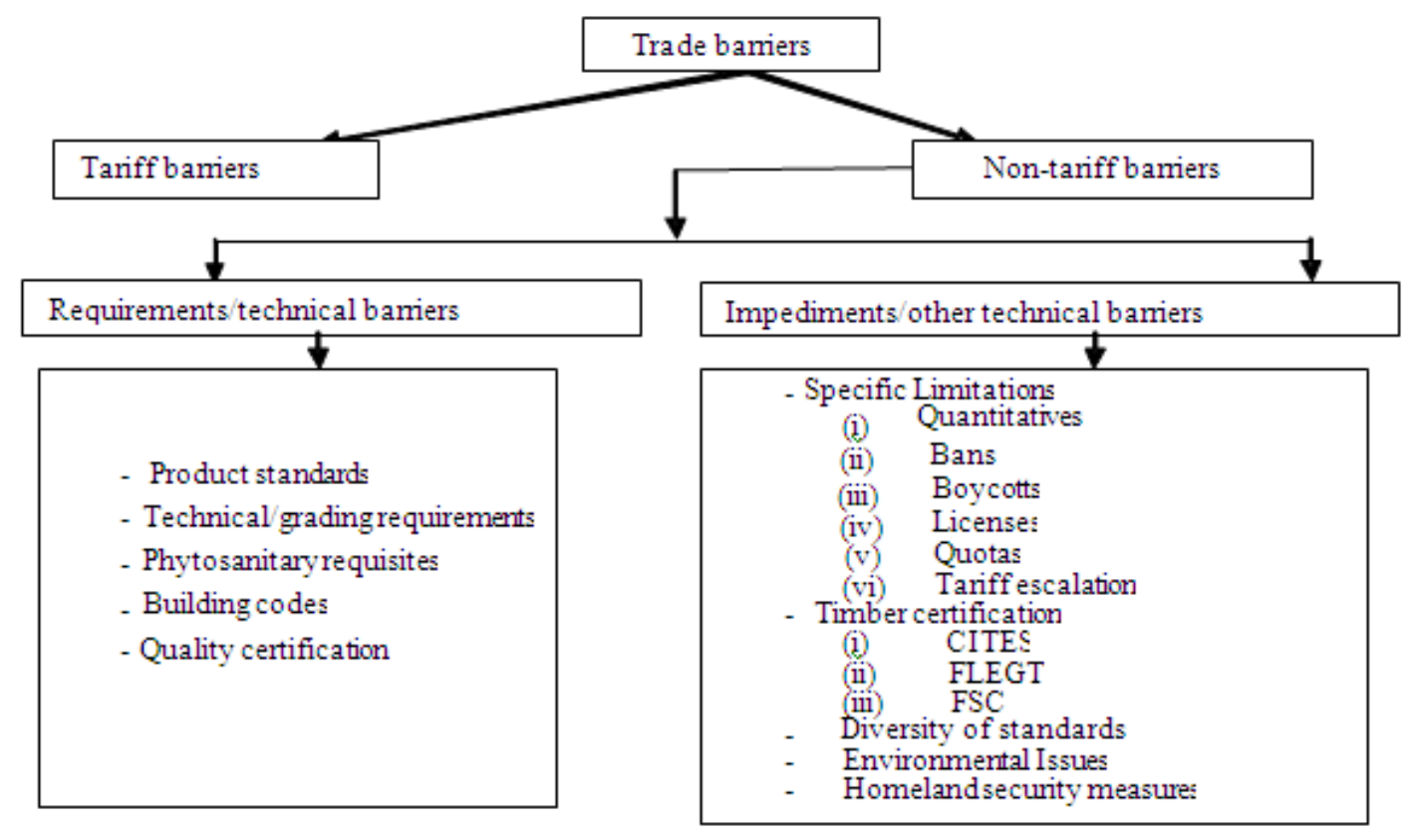

Fig. 1: Flow chart of non-tariff trade barriers affecting tropical timber, Source: (ITTO, 2005) 


\section{MATERIALS AND METHODS}

Data attainment: The study is conducted in University Kebangsaan Malaysia, Bangi since July, 2008 to December, 2009. The data for analysis is perceived from secondary sources for Malaysia. The significant manipulations for acquired data are import taxes and export taxes on timber trade and trade barriers. The corresponding outcomes are demonstrated from the analysis of collected data.

Reduced trade barriers to timber trade: A number of problems must be resolved before any further discussion of reduction of tariff and non-tariff trade measures. The WTO, with the mandate to promote trade liberalization, has an anti-environmental track record. Increased timber consumption will hurt forests and communities. Further lowering of timber tariffs will increase consumption of timber products, resulting in accelerated commercial logging and putting added pressure on the world's forests. There will be negative impacts on biodiversity, communities that rely on healthy forests and the local and global environments. The proponents of forest products liberalization are also targeting "non-tariff measures" for elimination.

Malaysia has cut its import tariffs by almost one half since 1993. The average applied most-favorednation tariff has declined from $15.2 \%$ in 1993 to $8.1 \%$ in 1997. In the implementation of the Uruguay round market access commitments, tariffs of a total of 3426 items have been reduced thus far. This included tariff reductions on 988 industrial products and 49 agricultural products. The tariff reduction exercises undertaken by the Ministry of Finance in October 1994 and in August 1995 saw tariffs being reduced on a total of over 3,000 items. This included tariff reductions on the 1,566 industrial items and 751 agricultural items. Of the industrial items, duties on 217 items were reduced at rate faster (acceleration) than that required under the WTO proportionate cuts reduction schedule, 318 items were reduced to their bound rates while 1,031 items were reduced to levels lower than the bound rates (deepening). For agricultural products, 80 items had their tariff rates reduced faster than was required, 147 items were reduced to their bound rates, while another 524 items had their tariff rates reduced lower than the bound rates. In the 1996 Budget excise tariffs on a total of 1,047 items were reduced. This included tariff reduction on 998 industrial items and 49 agricultural items. Of the industrial items 33 were reduced at a rate faster (acceleration), 125 items were reduced to their bound rates, while 840 items were reduced to levels lower than the bound rates (deepening). During the period 1992-96, investment in Malaysia averaged 40\% of GDP, with a considerable share coming from abroad, especially in manufacturing, where more than half of all firms' equity is now foreign-owned. Investments are encouraged by an array of tax and non-tax incentives granted (World Trade Organization, 1997).

Various sources have been consulted for data on tariff barriers. In turn, import-weighted average tariff rates were calculated for each region. The details of the import and export taxes and their anticipated effects are discussed below.

Import taxes: Before the Uruguay Round, most of the forest products tariff rates had very low levels like that $5 \%$. Primary timber products was had a little impact on import by the Uruguay round. Primary timber products tariff rates (logs and sawnwood) impact less than 5\% and plywood and veneer $10 \%$ and above. Many exporters from developing economies have been able to avoid the full MFN rates through special preference schemes, such as the Generalized System of Preferences (GSP). This is reflected in the lower import tariffs for some regions in Table 1-3. It is expected that the competitive benefit of GSPs to developing countries such as Malaysia and Indonesia, and 'Other Tropical' timber exporters will be reduced as the MFN tariffs decline through the Uruguay round measures.

Table 1: Tariff rates for logs (percentages)

\begin{tabular}{llllll}
\hline & Malaysia & Indonesia & Asian market & Other tropical & Other temperate \\
\hline Malaysia & & 0.0 & 0.0 & 0.0 & 0.0 \\
Indonesia & 0.0 & 0.6 & 0.0 & 0.0 & 0.0 \\
Asian market & 0.5 & 0.0 & 0.0 & 0.7 & 0.4 \\
Other tropical & 0.2 & 0.8 & 0.3 & 0.1 & 7.5 \\
Other temperate & 0.3 & &
\end{tabular}

Source: (Arunanondchai, 2001)

Table 2: Tariff rates for sawn wood (percentages)

\begin{tabular}{|c|c|c|c|c|c|}
\hline & Malaysia & Indonesia & Asian market & Other tropical & Other temperate \\
\hline Malaysia & & 0.0 & 0.0 & 0.0 & 0.0 \\
\hline Indonesia & 1.0 & & 10.0 & 10.0 & 10.0 \\
\hline Asian market & 3.1 & 2.4 & & 2.5 & 7.5 \\
\hline Other tropical & 0.3 & 2.6 & 0.2 & & 8.4 \\
\hline Other temperate & 0.3 & 0.7 & 0.8 & 0.5 & \\
\hline
\end{tabular}

Source: (Arunanondchai, 2001) 
Am. J. Environ. Sci., 6 (1): 95-102, 2010

Table 3: Tariff rates for plywood (percentages)

\begin{tabular}{lccccc}
\hline & Malaysia & Indonesia & Asian market & Other tropical & Other temperate \\
\hline Malaysia & & 45.0 & 45.0 & 45.0 & 45.0 \\
Indonesia & 20.0 & & 20.0 & 20.0 & 20.0 \\
Asian market & 8.1 & 8.1 & & 6.0 & 6.0 \\
Other tropical & 11.8 & 14.1 & 13.3 & 7.0 & 17.4 \\
Other temperate & 7.1 & 7.6 & 6.0 & & \\
\hline
\end{tabular}

Source: (Arunanondchai, 2001)

Table 4: Reductions in the UR tariffs on timber products only (in \% change)

\begin{tabular}{|c|c|c|c|c|c|}
\hline & Malaysia & Indonesia & Asian market & Other-tropical & Other temperate \\
\hline Welfare change $(\%)$ & 0.06 & 0.20 & -0.05 & 0.01 & 0.00 \\
\hline \multicolumn{6}{|c|}{ Producer's prices $(\%)$} \\
\hline Logs & 0.19 & 0.68 & -0.17 & 0.26 & 0.07 \\
\hline Sawn wood & 0.18 & 0.41 & -0.06 & 0.02 & 0.03 \\
\hline Plywood & 0.17 & 0.47 & -0.05 & 0.13 & 0.02 \\
\hline \multicolumn{6}{|l|}{ World price (\%) } \\
\hline Logs & 0.19 & 0.68 & -0.17 & 0.26 & 0.07 \\
\hline Sawn wood & 0.18 & 0.41 & -0.06 & 0.02 & 0.03 \\
\hline Plywood & 0.17 & 0.47 & -0.05 & 0.13 & 0.02 \\
\hline \multicolumn{6}{|l|}{ Production (\%) } \\
\hline Logs & 0.04 & 0.15 & -0.03 & 0.12 & 0.02 \\
\hline Sawn wood & -0.22 & -0.23 & -0.24 & 0.04 & 0.29 \\
\hline Plywood & 1.18 & 0.84 & -0.07 & 0.33 & 0.17 \\
\hline \multicolumn{6}{|l|}{ Exports (\%) } \\
\hline Logs & -0.41 & -0.73 & 0.87 & -0.15 & -0.38 \\
\hline Sawn wood & -0.34 & -0.90 & 0.17 & 0.05 & 4.04 \\
\hline Plywood & 1.20 & 0.96 & 0.95 & 1.23 & 0.99 \\
\hline
\end{tabular}

Source: (Arunanondchai, 2001)

When carrying out the model simulations, it has been assumed that there are no changes in the GSP tariffs. Given that most tropical countries faced the GSP rates prior to the Uruguay round, the trade-weighted changes in tariffs facing these countries post-Uruguay round are expected to be smaller than those faced by the developed countries. In turn, there could be some trade diversion away from developing countries towards developed countries' imports. The elasticity of substitution between wood products from different sources will be crucial in determining the extent of such trade diversion. The pre-Uruguay round weighted average tariff rates for each region and each production category are displayed in Table 1-3. Not only are they substantially higher in developing countries than in developed countries, but in general, tariffs on wood products tend to escalate with the degree of processing.

Note: In the Table 1-3, columns represent exporters and rows represent importers.

Export taxes: Trade barriers on log exports such as export taxes, quotas and bans has been a trend over the past thirty years. Indonesia was one of the first countries to have banned log exports; however in 1985 it replaced the ban with prohibitive export taxes, ranging between US\$500-US\$4, $800 \mathrm{~m}^{-3}$. Since 1989, specific export taxes have been imposed on sawnwood to promote plywood exports, which are exempted from all taxes.

As for Malaysia, both Peninsular Malaysia and Sabah have prohibited the export of logs since 1994; while Sarawak imposes an export tax of 15\%. Export tax rates were introduced on sawnwood and plywood in 1996. Another major exporter in Southeast Asia is Papua New Guinea who imposed a 13\% log export tax in 1995 (Table 4).

\section{RESULTS}

Role of trade barriers to timber trade in Malaysia: Trade barriers to timber trade are an important role in the forestry sector. It is widely used by both developed and developing countries. Barriers affecting forest products influence the developing countries in a number of ways-both positively and negatively. Import barriers erected by the major markets affect both the level of trade and the form of forest products traded by the developing countries. The level of trade is affected by the absolute size of any particular barrier and the form of forest products imported is affected by the relative size of the barriers between different products. Developing countries use import barriers to both gain revenue and limit the import of products which may inhibit the development of their own industries. In particular, high tariff rates are used to protect domestic 
wood processing industries from cheaper imports. Export taxes have been used by developing countries to both raise revenue and influence industrial development. Taxes on a range of products, including forest products, have been an important source of government revenue. In many developing countries, trade in tropical timber products is circumscribed by highly interventionist policies, implemented in order to foster domestic processing industry. The major exporters of tropical timber products, Indonesia, Malaysia and Brazil, have banned log exports (Andersson, 1997).

The extent to which domestic industry is protected by trade barriers and hence the extent to which exporters may find it difficult to compete on export markets, invariably focuses on the most visible element of any protection being provided-the level of import tariffs, size of quotas, level at which price guidelines are set.

Non-Tariff Barriers (NTBs) can severely hinder trade and erode the benefits of tariff elimination. Forest products increasingly rely on technical regulations, standards and related procedures for their acceptance in the global marketplace. Forest and wood products sector-specific discussions toward reduction or elimination of NTBs represent a real opportunity that, if successful, could provide meaningful progress toward achieving free and fair trade in this sector. Log export bans can protect forests by reducing logging and by limiting illegal logging and export of timber. These bans can also be economically beneficial by increasing production of value-added products which provide more income per tree. The WTO may eliminate 'nontariff' barriers such as log export bans; this will severely hamper efforts to protect forests.

Malaysia is one of the highest profile international environmental struggles of the 1990s aimed to protect tropical forests which hold great biological diversity and are home to many indigenous tribes which continued their traditional lifestyles until recently. The Penang tribes living have lived in Sarawak, Malaysia on the island of Borneo for thousand of years. But logging of their traditional forests has all but destroyed their traditional ways of life. Much of the timber was exported to Japan to manufacture plywood for disposable construction materials.

During the period of 2000-2005, Malaysia has continued to liberalize its policies on international trade and foreign investment. Indeed, imports and exports of goods, respectively, were on average equivalent to $86 \%$ and $110 \%$ of GDP during this period. Inflows of Foreign Direct Investment (FDI), although down from the high level of $7 \%$ of GDP between 1990 and 1997, were still around 3\% of GDP during the period 199904, a level more in line with the world average. As a consequence of trade openness with prudent macroeconomic and structural reforms in key areas, Malaysian's economy achieved a steady growth rate following the trade liberalization and fully recovered from the Asian financial crises in 1997-98. Growth in real GDP, after slowing to $0.3 \%$ in 2001 , owing to a contraction in exports, rebounded to $4.4 \%$ in 2002 , $5.4 \%$ in 2003 and $7.1 \%$ in 2004. Malaysia's current account surplus widened from $8.3 \%$ of GDP in 2001 to $12.6 \%$ of GDP in 2004. The current account position is due to merchandise trade (World Trade Organization, 2005). There has been little change in Malaysia's traderelated institutional framework from 2001-2005; however, Malaysia has continued efforts to liberalize its relatively open trade and investment regime and joined the trend in the south-east Asian (ASEAN) region of seeking closer economic relations at both the regional and bilateral levels. Also in investment liberalization, equity holdings in all new manufacturing projects have been fully liberalized; foreign investors can now hold $100 \%$ equity in all investments. During the period 2001-2005, Malaysia's economy has remained relatively open to trade and foreign investment. The tariff continues to be the main border measure affecting imported goods and accounted for $5.4 \%$ of overall tax revenue in 2004. However, applied tariffs have come down in successive annual budget exercises to an MFN average applied rate of $8.1 \%$ in 2005 , compared to 9.2\% in 2001. Patterns of MFN tariff dispersion and escalation have changed little since 2001 (World Trade Organization, 2005).

The coverage of tariffs was gradually reduced in the late 1980s and 1990s, especially with the launching of the AFTA and the commitments made to the WTO for greater liberalization. Malaysia's tariff regime currently compares favorably with many other Asian countries (Table 5). In some sectors, however, average tariff rates are relatively high, giving protection to particular industries, like foodstuffs, plastics, textiles, footwear and vehicles.

By realizing the effect of tariff, decision makers can manage the appropriate trade policy. Trade policy is related to both the foreign exchange rate policy and policies concerning with the set of either tariff barriers or non-tariff barriers as well as free trade imposed by the host country. Host country can apply the import substitution strategy (inward looking strategy) or export oriented strategy (outward looking strategy) or mixed strategy (both import substitution and export oriented strategy). Based on the nation's macroeconomic situation, the nation must implement the effective trade policy and trade strategy efficiently. 
Am. J. Environ. Sci., 6 (1): 95-102, 2010

Table 5: Weighted mean tariff barriers, selected Asian countries and selected years

\begin{tabular}{|c|c|c|c|c|}
\hline Country & Year & All products & Primary products & Manufactured products \\
\hline \multirow{2}{*}{ China } & 1992 & 232.1 & 14.1 & 35.6 \\
\hline & 2004 & 6.0 & 5.6 & 6.0 \\
\hline \multirow[t]{2}{*}{ India } & 1990 & 56.1 & 34.1 & 70.8 \\
\hline & 2004 & 28.0 & 36.9 & 25.3 \\
\hline \multirow[t]{2}{*}{ Indonesia } & 1989 & 13.0 & 5.9 & 15.1 \\
\hline & 2003 & 5.2 & 3.1 & 5.8 \\
\hline \multirow[t]{2}{*}{ Japan } & 1988 & 3.6 & 4.4 & 2.7 \\
\hline & 2004 & 2.4 & 3.9 & 1.6 \\
\hline \multirow[t]{2}{*}{ South Korea } & 1988 & 14.0 & 8.3 & 17.0 \\
\hline & 2002 & 10.0 & 19.0 & 5.0 \\
\hline \multirow[t]{2}{*}{ Malaysia } & 1988 & 9.7 & 4.6 & 10.8 \\
\hline & 2003 & 4.2 & 2.1 & 4.6 \\
\hline \multirow[t]{2}{*}{ Pakistan } & 1995 & 14.4 & 36.1 & 49.2 \\
\hline & 2004 & 13.0 & 8.9 & 15.7 \\
\hline \multirow[t]{2}{*}{ Philippines } & 1988 & 22.4 & 18.5 & 23.4 \\
\hline & 2003 & 2.6 & 5.0 & 2.0 \\
\hline \multirow[t]{2}{*}{ Singapore } & 1989 & 1.1 & 2.5 & 0.6 \\
\hline & 2003 & 0.0 & 0.0 & 0.0 \\
\hline \multirow[t]{2}{*}{ Thailand } & 1989 & 33.0 & 24.3 & 35.0 \\
\hline & 2003 & 8.3 & 4.4 & 9.3 \\
\hline \multirow{2}{*}{ Vietnam } & 1994 & 20.6 & 46.7 & 13.1 \\
\hline & 2004 & 13.7 & 16.7 & 12.5 \\
\hline
\end{tabular}

Source: (World Bank, 2005)

Table 6: Tariff and Non-tariff barriers in selected timber importing countries $2007\left(000^{\prime} \mathrm{m}^{3}\right)$

\begin{tabular}{|c|c|c|c|c|c|c|c|c|c|c|}
\hline \multirow[b]{3}{*}{ Item } & \multicolumn{10}{|c|}{ Market } \\
\hline & \multicolumn{3}{|l|}{$\mathrm{EC}$} & \multicolumn{3}{|l|}{ Japan } & \multicolumn{2}{|c|}{ Australia } & \multicolumn{2}{|l|}{ USA } \\
\hline & $\begin{array}{l}\text { Tariff } \\
\text { rate\% }\end{array}$ & $\begin{array}{l}\text { Tariff rate } \% \text { under } \\
\text { GSP for Malaysia }\end{array}$ & $\begin{array}{l}\text { Non- } \\
\text { tariff }\end{array}$ & $\begin{array}{l}\text { Tariff } \\
\text { rate } \%\end{array}$ & $\begin{array}{l}\text { Tariff rate } \\
\text { under MJEPA }\end{array}$ & $\begin{array}{l}\text { Non- } \\
\text { tariff }\end{array}$ & $\begin{array}{l}\text { Tariff } \\
\text { rate } \%\end{array}$ & $\begin{array}{l}\text { Non- } \\
\text { tariff }\end{array}$ & $\begin{array}{l}\text { Tariff } \\
\text { rate } \%\end{array}$ & $\begin{array}{l}\text { Non- } \\
\text { tariff }\end{array}$ \\
\hline \multicolumn{11}{|l|}{ Sawnwood } \\
\hline Hardwood & $0-4.9$ & $0-0$ & +++ & 6 & 0 & Nil & $0-5$ & $*$ & Free & $* *$ \\
\hline Softwood & Free & & +++ & $4.8-6$ & 0 & Nil & $0-5$ & $*$ & Free & $* *$ \\
\hline $\begin{array}{l}\text { Veneer } \\
\text { Hardwood }\end{array}$ & $0-6$ & $0-0$ & +++ & $5-6$ & 0 & Nil & $0-5$ & * & Free & $* *$ \\
\hline Softwood & $0-4$ & & $\begin{array}{l}\text { TTT } \\
+++\end{array}$ & $5-6$ & 0 & Nil & $0-5$ & * & Free & $* *$ \\
\hline Plywood & & & & & & & & & & \\
\hline Hardwood & $6-10$ & $2.5-6.5$ & +++ & $6-10$ & $6-10$ & Nil & 5 & * & Free & $* *$ \\
\hline Softwood & $6-7$ & & +++ & 6 & 6 & Nil & 5 & $*$ & Free & $* *$ \\
\hline
\end{tabular}

Source: (MTIB, 2008); Australia*: Several state governments and local councils place restrictions on the use of tropical timbers. USA**: Several states and local councils introduced bills that restrict or discriminate the use of tropical timber. EU: +++ (1) CE marking is compulsory in EU for manufactures who export wood based panels used for the building construction materials (2) Timber certification: Certification for timber sourced from forest that is sustainably managed is increasingly being demanded. However, the preference for certain certification scheme discriminates timber which is certified under the national scheme such as in a MTCC scheme

Barriers and trade policy in Malaysia: Trade in timber products has become increasingly global in recent years, with the number of countries exporting and importing various timber products growing. Barriers have become increasingly important as more processed products are traded, with both tariff and nontariff barriers becoming more prevalent. The effect is to restrict the ability of the developing countries to produce more processed products which provide the opportunity for increased economic and social development. Major developed countries which maintain high tariffs on some of these products include USA, Japan, the EEC and Australia. Developing countries themselves generally have higher rates than those in place in the developed countries. Tariff restrictions have been declining steadily for a number of years. In recent years tariff barriers have declined in most of the main import markets. The extent of the decline differs with the market and the specific product, but few developed country tariffs are now particularly high for most timber products. This is shown for selected countries in the (Table 6) which provides a general indication of rates for selected countries. With the exception of some products in some markets, tariffs for timber products in developed countries are generally less than $5 \%$ for most products. 
As the results of the Uruguay Round are implemented, tariffs will continue to decline. Tariffs in developed countries such as the European Union, Japan, Australia and the United States on some timber products will be reduced to very low levels, or eliminated. Non-tariff barriers are much more difficult to identify and evaluate. Nevertheless the wide array that exist, the increasing frequency with which many appear and the number that can apply to a given product suggest they are a problem. They are a greater problem for the developing countries than for developed country exporters. NTMs which may act as barriers to trade:

- Specific limitations on trade: Quantitative restrictions; export restraints; health and sanitary regulations; licensing; embargoes and minimum price regulations

- Charges on imports: Tariffs; variable levies; prior deposits; special duties on imports and internal taxes

- Standards: Industrial standards; packaging; labeling and marking regulations

- Government interventions in trade: Government procurement; stock trading; export subsidies; countervailing duties and trade diverting aid

- Customs and administrative entry procedures: Customs valuation; customs classification; antidumping duties; consular and customs formalities and requirements and sample requirements

The greatest impact on trade flows will continue to be from the export barriers imposed by the developing countries themselves. The effect of these restrictions will depend on a number of factors including the extent to which importers can find alternative sources of supply. Indications are that as long as the government of Malaysia continues to be willing to maintain the barriers by effectively subsidizing domestic log prices and to continues to provide the regional support for processing development.

\section{DISCUSSION}

Malaysia's simple average applied tariff rate is $8.4 \%$, but duties for tariff lines where there is significant local production are often higher. The level of tariff protection is generally lower on raw materials than for value added goods. Malaysia maintains performance requirements that are needed to receive a customs waiver for operations in foreign trade zones. In 2008, the Malaysian government implemented TariffRate Quota (TRQ) systems for some tariff rates, which include products such as timber products. This product now incurs in-quota duties between 10 and $25 \%$ and out-of-quota duties as high as between 40 and $50 \%$. Before TRQ implementation, the applied tariff rate was zero for these products.

Malaysia taxes exports of timber products in order to protect domestic processing production. Malaysia is one of the largest producer and largest exporter of timber products of world production. The Malaysian government waives export taxes on exports of timber products to Malaysia-invested foreign timber that include investment by Malaysian persons, giving Malaysia-invested plants a competitive advantage in foreign markets, including the United States.

Although in general formal trade barriers are not a serious problem for timber trade in most situations, for certain products in certain markets, they create difficulties. In these cases and to ensure that non-tariff measures do not increase it is important that continued efforts are placed on containing or reducing them. While recognizing the value of efforts on trade barriers it is worth emphasizing that improvement in timber sector development to support export activities are of much more importance. Positive steps must be taken if the impact of import trade barriers is to be reduced. It is not sufficient to leave any improvement to the goodwill of the countries concerned, since there is little evidence to suggest that major changes will take place unless either clear benefit exists for the importing countries.

Efforts to reduce these barriers should take place at a number of different levels and can be broadly considered in three categories. Those which:

- Reduce barriers

- Make it easier to avoid or overcome barriers

- Reduce the importance of barriers

Government and country trade associations can provide an input at a more detailed level which identifies and implements programmes which meet their own specific needs. They must also provide the input which ensures effective action at both the regional and international level.

\section{CONCLUSION}

In progressing towards trade liberalization of the timber products sector, mixed effects on the forest rent and timber production in different regions can be detected. Therefore, a reduction in trade barriers does not always lead to increased log production as feared by some non-governmental organizations. Amongst other things, the direction of change in log production 
depends on the Malaysian log prices and factor prices. When the Uruguay Round policy changes are implemented in the forest sector alone, the welfare and terms of trade of all tropical regions improve. There was a significant fall between 1997 and 1998, which coincided with the start of the Asian economic crisis and thereafter the outputs have not recovered. The production of Malaysian plywood rose substantially over the decade but experienced a mild fall between 1997 and 1998, also due to the economic crisis. Tariff liberalization may also lead to positive environmental changes by stimulating increases in manufacturing efficiency in export-oriented developing countries. In addition, trade liberalization in timber products is most likely only as part of a broader set of reduction in tariff and other trade barriers. Most Favored Nations (MFN) status has been developed and promoted by General Agreement on Tariffs and Trade (GATT) and the World Trade Organization (WTO to increase efficiency in production through international trade around the globe.

The implications of trade liberalization for individual Timber Committee members will vary depending on whether the member is primarily an exporter or an importer, on the products traded and the countries traded with. The impact will also depend on what activities is being undertaken-growing, trading, retailing etc. Reductions or complete elimination of many tariffs and quantitative restrictions and further progress on strengthening the rules surrounding nontariff measures to limit or remove their ability to be used as NTBs. In this forestry would benefit most from the efforts that will occur in the SPS and the TBT Agreements. Further reductions in import tariffs will open up markets, but since most rates are currently not high, the effect will not be great.

\section{ACKNOWLEDGEMENT}

Financial assistance provided by the Research University Grant (GUP), UKM-GUP-ASPL-07-06-011. Institute for environment and development, University Kebangsaan Malaysia is gratefully acknowledged.

\section{REFERENCES}

Andersson, T., 1997. The tropical forests as a global resource: Impacts of trade-related policy. Working Paper Series in Economics and Finance No. 187. http://ideas.repec.org/p/hhs/hastef/0187.html

Arunanondchai, M., 2001. Trade policy and the welfare of Southeast-Asian timber exporters: Some implications for forest resources. http://ideas.repec.org/p/eep/report/rr2001091.html
Barbier, E.B., 1995. Trade in timber-based forest products and the implications of the Uruguay round. FAO Unasylva, 46: 3-10. http://www.fao.org/docrep/v7850e/V7850e02.htm

Barbier, E.B., 1999. Timber Trade and Environment: In World Forest, Society and Environment, Palo, M. and J. Uusivuori (Eds.).

Bourke, I.J. and J. Leitch, 1998. Trade restrictions and their impact on international trade in forest products. FAO, Rome. http://www.eldis.org/assets/Docs/27664.html

Bourke, I.J. and J. Leitch, 2000. Trade Restrictions and Their Impact on International Trade in Forest Products. FAO. Rome. http://www.fao.org/waicent/faoinfo/forestry/ FOP/FOPH/bkleich/B98-1.htm.

Bourke, I.J., 1988. Trade in Forest Products: A Study of the Barriers Faced by the Developing Countries. FAO, Rome, pp: 140.

Bourke, I.J., 1995. International trade in forest products and the environment. FAO Unasylva, 46: 11.

ITTO, 2005. Revised ITTO criteria and indicators for sustainable management of tropical forests including reporting format. ITTO Policy Development. Series No. 15. ITTO, ISBN: 4902045-20-6, pp: 1-40.

MTIB, 2008. Statistics on Commodities. 22nd Edn., Ministry of Plantation. Industries and Commodities, Malaysia. ISSN: 1394-5882.

Philippidis, G. and A.I. Sanjuan, 2007. An examination of morocco's trade options with the EU. J. African Econ., 16: 259-300.

Rytkonen, A., 2003. Market access of tropical timber. Final report submitted to the 34th Session of the International Tropical Timber Council, Porvoo, Finland.

World Bank, 2005. Economic Report. World Bank Publications, USA.

World Trade Organization, (WTO), 2005. Annual Report. WTO Publications, World Trade Organization, Geneva.

World Trade Organization, (WTO), 1997. Environmental Benefits of Removing Trade Restrictions and Distortions.

Zhu, S., J. Buongiorno and D.J. Brooks, 2001. Effects of accelerated tariff liberalization on the forest products sector: A global modeling approach. Forest Policy Econ., 2: 57-78. 